\title{
Ecology of Germination and Flowering in the Weedy Winter Annual Grass Bromus japonicus
}

\author{
J.M. BASKIN AND C.C. BASKIN
}

Abstract

From the time of seed maturity in late June and early July until December when temperatures drop to near freezing, habitat temperatures are within the range of those required for germination of seeds of the winter annual Bromus japonicus. However, a large proportion of the seeds in a given seed crop fail to germinate in the autumn of the year in which they are produced because they are not dispersed until winter. A high percentage of of the winterdispersed seeds is induced into dormancy and must undergo a period of afterripening the following summer before germination can occur the next autumn. Thus, many of the plants that become established at a population site in autumn are from the previous year's seed crop. Plants overwinter in the field as "rosettes" and require long days for flowering. Nonvernalized plants exposed to natural short photoperiods of late autumn and winter flower under long days in spring, but plants flower much sooner if they are subjected to both low temperatures (vernalization) and short photoperiods during winter.

Bromus japonicus Thunb. (Japanese chess) is a native Eurasian winter annual that has been introduced into the United States where it ranges from Vermont to the state of Washington south to North Carolina and California (Hitchcock 1935, Fernald 1950). As is true for some other introduced bromegrasses in the United States, B. japonicus is a problem in wheat fields, in grass and alfalfa seed fields, and in pastures, meadows, and overgrazed range lands (Slife et al. 1960, Finnerty and Klingman 1962, Steyermark 1963). To better understand the ecological life cycle of this weedy winter annual, we have studied (1) the role of temperature in controlling the timing of germination in nature and (2) the influence of vernalization and photoperiod on the timing of flowering.

In northcentral Kentucky where we have observed its phenology, B. japonicus begins to flower in early May, and caryopses (hereafter referred to as seeds) are ripe by late June or early July. Plants senesce as the seeds mature, and there are no living plants at a population sitc during summer. The seeds are retained on the dead erect shoots until autumn and winter. Seed dispersal begins in early October, and continues until the following March, with a high percentage of the seeds being dispersed during November, December, and January. Seed germination occurs in early autumn, and thousands of seedlings may appear at a population site at any time from early September to mid October, depending upon the time when soil moisture conditions become suitable for germination. Only an occasional seedling is found in the field in spring. Since germination occurs before very many of the seeds are shed, population establishment each year results primarily from germination of a reserve of seeds present in and/or on the soil surface. Following germination, each plant produces a "rosette" of 10-15

\footnotetext{
Authors are associate professor and researcher, School of Biological Sciences, University of Kentucky, Lexington, Kentucky 40506.

This project was financed in part with funds from the U.S. Environmental Protection Agency under grant number CR-806277-02. The contents do not necessarily reflect the views of the EPA.

Manuscript received December 20, 1979.
}

leaves, and the plants overwinter in this stage. Flower buds are initiated in early April, at which time the plants also begin to bolt.

\section{Methods}

\section{Germination Characteristics of Seeds Taken from the Field}

Seeds that matured in the spring of 1975 were used to study the temperature responses of seeds of different ages in light and darkness. At the beginning of each month from July, 1975 to March, 1976, seeds were collected from dead, erect plants in the field and used immediately in germination tests. On March 1, 1976, seeds were collected from plants in the field and placed in fine-mesh nylon bags on the soil surface at a B. japonicus population site. (By April 1, 1976, all of the seeds had been dispersed.) In early April, May, June, and September, 1976, seeds were removed from the bags and used in germination tests.

Germination tests were conducted in temperature- and lightcontrolled incubators at $12 / 12 \mathrm{hr}$ alternating temperature regimes of $15 / 6,20 / 10,30 / 15$ and $35 / 20^{\circ} \mathrm{C}\left( \pm 1^{\circ} \mathrm{C}\right)$ at a 14-hr photoperiod and in continuous darkness. The photoperiod extended from $1 \mathrm{hr}$ before the beginning of the high temperature period to I hr after the beginning of the low temperature period. The light source was 20-W cool white fluorescent tubes, and light intensity at seed level was approximately $2.1 \mathrm{Klx}$. Seeds were incubated in $9 \mathrm{~cm}$ Petri dishes on clean, white quartz sand moistened with distilled water. All dishes were wrapped with plastic film, and dishes containing seeds to be incubated in darkness also were wrapped with aluminum foil. Three replications of 50 seeds each were used for each treatment. Germination percentages were determined after 30 days, and protrusion of the radicle was the criterion of germination. Germination percentages were rounded off to the nearest whole number.

Seeds collected on December 6, 1977, were used in a second field experiment to test the effect of winter habitat conditions on the subsequent germination of the seeds. Some of the freshly collected seeds were used to test initial germination, others were stored in bags on the soil surface at a $B$. japonicus population site, and still others were stored in a closed, glass bottle at $25 \pm 2^{\circ} \mathrm{C}$ in the laboratory. On March 30,1978, seeds stored in the field and in the laboratory were tested for germination. Field-stored seeds that failed to germinate in the incubators were stored in a nonheated greenhouse (no heating or air-conditioning and windows open all year) during the summer of 1978 and tested in light at $20 / 10^{\circ} \mathrm{C}$ in October, 1978. Thermograph records made in the greenhouse were used to calculate mean daily maximum and minimum monthly temperatures from 1970 through 1978 (Baskin and Baskin 1979).

\section{Seed Reserves in the Soil}

Phenological observations indicated that many of the seedlings that become established at a population site in autumn are from seeds produced during the past year(s) rather than from seeds produced during the current year. To determine if viable, ungerminated seeds are present at a population site after the germination season is finished, four blocks of soil, each $6 \mathrm{dm}^{2}$ and $5 \mathrm{~cm}$ deep, were collected in Jessamine County, Kentucky, on April 9, 1976. 
Any seeds in the soil would have been from at least the 1975 seed crop. The blocks of soil were fitted into small flats and placed in the nonheated greenhouse until April 3, 1978. The soil blocks were watered to field capacity once each week from May 1 to August 31 and were watered daily during the remainder of the year, except when the soil was frozen in winter. These watering regimes were given to approximate the soil moisture conditions that seeds might conceiveably be exposed to in the field. The flats were examined at weekly intervals for newly germinated seeds, and if seedlings were present they were counted and removed.

\section{Vernalization and Flowering}

In this experiment, flowering of vernalized and nonvernalized plants was compared. Freshly collected seeds were planted on October 3, 1974, and on October 14, 1974, the resulting seedlings were transplanted; one seedling was placed in each of $22010-\mathrm{cm}$ clay pots filled with soil. On this date 20 plants were placed in a greenhouse that was heated during winter (heated controls), and the other 200 plants were kept in the nonheated greenhouse. On November 1 and 15 and December 3 and 15, 1974, and on January 1 and 15, February 1 and 15, and on March 1, 1975, 20 plants were transferred from the nonheated to the heated greenhouse. The remaining 20 plants were kept in the nonheated greenhouse (nonheated controls). Plants in both greenhouses were exposed to natural photoperiods. Throughout the experiment the plants were watered daily and examined once each week for flowering. Temperatures in the heated greenhouse ranged mostly from 20 to $30^{\circ} \mathrm{C}$ during the day and from 15 to $20^{\circ} \mathrm{C}$ at night. From the thermograph records, we determined the number of hours that plants in the nonheated greenhouse were exposed to temperatures between 0.5 and $10^{\circ} \mathrm{C}$. According to Leopold (1964), the optimum temperature range for vernalization of most plants is 0 to $5^{\circ} \mathrm{C}$, but temperatures from a few degrees below 0 to $10^{\circ} \mathrm{C}$ are effective.

\section{Photoperiod and Flowering}

To study the photopcriod requirement for flowering in vernalized and nonvernalized plants, seedlings from seeds that germinated in September 1975 were potted individually in $10-\mathrm{cm}$ pots and grown in the nonheated and heated greenhouse until January 13,1976 . On this date, 15 vernalized and 15 nonvernalized plants were placed in each of two growth chambers, one set on a short day (SD) and the other on a long day (LD) photoperiod regime. Light intensity at plant level averaged about $9.0 \mathrm{Klx}$ of cool white fluorescent light. Plants in the SD chamber received a 10-hr light period each day and those in the LD chamber received an 8-hr light period plus $2 \mathrm{hr}$ of light in the middle of the dark period. The two chambers were set on a $12 / 12 \mathrm{hr}$ daily thermoperiod of $25 / 20^{\circ} \mathrm{C}$. In the SD chamber the high temperature period extended from $1 \mathrm{hr}$ before the beginning of the light period to $1 \mathrm{hr}$ after it ended, and in the $\mathrm{LD}$ chamber the high temperature period extended from $2 \mathrm{hr}$ before the beginning of the light period to $2 \mathrm{hr}$ after it ended. Therefore, the light break in the LD chamber occurred during the lower temperature of the daily thermoperiod. The plants were watered daily and checked every 3 to 5 days for flowers. The experiment was terminated after the plants had been in the chambers for 218 days.

During the autumn and winter of 1976-77, the photoperiod experiment was repeated using only vernalized plants. On February $25,1977,20$ plants were transferred from the nonheated greenhouse to each of the two growth chambers. Conditions were the same as those previously described except the thermoperiod was $30 / 20^{\circ} \mathrm{C}$.

\section{Results}

Germination Characteristics of Seeds Taken from the Field

When freshly matured seeds were collected and tested in July, 1975 , they exhibited a slight degree of dormancy. That is, $33 \%$ or more of them failed to germinate when incubated over the range of temperatures in light and darkness (Table 1). The best germination was $67 \%$, at $15 / 6^{\circ} \mathrm{C}$ in light. The seeds afterripened during the summer, and those collected in autumn germinated to nearly $100 \%$ at all temperature regimes in light and darkness. During winter, germination percentages of seeds collected from plants in the field showed a big decrease in both light and darkness at 30/15 and $35 / 20^{\circ} \mathrm{C}$. Further, seeds placed on the soil surface in March entered dormancy and germinated to $13 \%$ or less at all conditions when tested in April. Seeds were still dormant in May and June, but by September they germinated to $71 \%$ or more in light and darkness at $20 / 10$ and $30 / 15^{\circ} \mathrm{C}$.

Table 1. Germination of Bromus japonicus seeds collected from plants in the field on various dates or of seeds taken from bags on soil surface.

\begin{tabular}{|c|c|c|c|c|c|c|c|c|}
\hline \multirow{3}{*}{$\begin{array}{l}\text { Date germination } \\
\text { tests began }\end{array}$} & \multicolumn{8}{|c|}{ Germination temperatures $\left({ }^{\circ} \mathrm{C}\right)$} \\
\hline & \multicolumn{4}{|c|}{ 14-h photoperiod } & \multicolumn{4}{|c|}{ Darkness } \\
\hline & $15 / 6$ & $20 / 10$ & $30 / 15$ & $35 / 20$ & $15 / 6$ & $20 / 10$ & $30 / 15$ & $35 / 20$ \\
\hline July 2,1975 & 67 & 57 & 63 & 39 & 45 & 31 & 37 & 17 \\
\hline Aug. 1, 1975 & 100 & 100 & 100 & 86 & 100 & 100 & 99 & 31 \\
\hline Sept. 1, 1975 & 99 & 100 & 100 & 100 & 100 & 99 & 99 & 100 \\
\hline Oct. 5,1975 & 100 & 100 & 100 & 99 & 99 & 100 & 100 & 99 \\
\hline Nov. 5,1975 & 100 & 100 & 100 & 96 & 100 & 100 & 100 & 99 \\
\hline Dec. 3, 1975 & 100 & 100 & 100 & 98 & 99 & 100 & 100 & 87 \\
\hline Ian. 7,1976 & 100 & 92 & 65 & 17 & 100 & 97 & 67 & 11 \\
\hline Feb. 1,1976 & 94 & 92 & 56 & 26 & 78 & 90 & 46 & 9 \\
\hline March 1, 1976 & 85 & 77 & 52 & 29 & 79 & 74 & 48 & 23 \\
\hline April 8,1976 & 9 & 13 & 1 & 2 & 3 & 8 & 2 & 1 \\
\hline May 4,19761 & 17 & 2 & 7 & 1 & 0 & 6 & 7 & 1 \\
\hline June 9,1976 & 31 & 13 & 1 & 1 & 7 & 15 & 1 & 0 \\
\hline Sept. $1,1976^{1}$ & 15 & 73 & 82 & 44 & 16 & 85 & 71 & 12 \\
\hline
\end{tabular}

'Seeds taken from bags on soil surface.

Seeds collected in December, 1977, germinated to $91 \%$ or more at $15 / 6,20 / 10$, and $30 / 15^{\circ} \mathrm{C}$ in both light and darkness. However, after 16 weeks of storage in the field, seeds incubated at 15/6, $20 / 10$, and $30 / 15^{\circ} \mathrm{C}$ germinated to 23,21 , and $19 \%$, respectively, in light and to 22,14 , and $11 \%$, respectively, in darkness. Laboratorystored seeds germinated to $97 \%$ or more at the three temperature regimes in both light and darkness. The field-stored seeds that failed to germinate in the incubators in early spring afterripened in the nonheated greenhouse during summer and germinated to $98 \%$ in light at $20 / 10^{\circ} \mathrm{C}$ in October.

\section{Seed Reserves in the Soil}

Bromus japonicus seeds began to germinate in the flats in late August, 1976, and continued to germinate through the middle of October, 1976. A total of 558 seeds germinated in the four flats, which is equivalent to 2,325 seedlings $/ \mathrm{m}^{2}$. There was no additional germination until autumn, 1977, when one seed germinated in September and two germinated in October.

\section{Vernalization and Flowering}

All plants survived and eventually flowered; therefore, vernalization is not an absolute requirement for flowering in B. japonicus (Fig. 1). Increases in the number of hours of vernalization shortened the time to $100 \%$ flowering after plants were moved to the heated greenhouse. The number of hours of vernalization received by each group of plants and the date when the last plant in a group flowered were: 0 and $118 \mathrm{hr}$ on July $29 ; 280 \mathrm{hr}$ on June $12 ; 485 \mathrm{hr}$ on May $31 ; 615$ and $756 \mathrm{hr}$ on May 27;827, 1,070,1,206, and $1,408 \mathrm{hr}$ on May 17. Plants in the nonheated greenhouse received $1,870 \mathrm{hr}$ of vernalization and all of them flowered by May 17 .

\section{Photoperiod and Flowering}

None of the vernalized or nonvernalized plants flowered under SDs, while all of the vernalized and nonvernalized plants flowered under LDs. Flowering of vernalized plants receiving LDs was completed 61 days after transfer to the LD chamber, but 163 days elapsed before all the nonvernalized plants flowered. In the second photoperiod experiment using only vernalized plants, all plants 


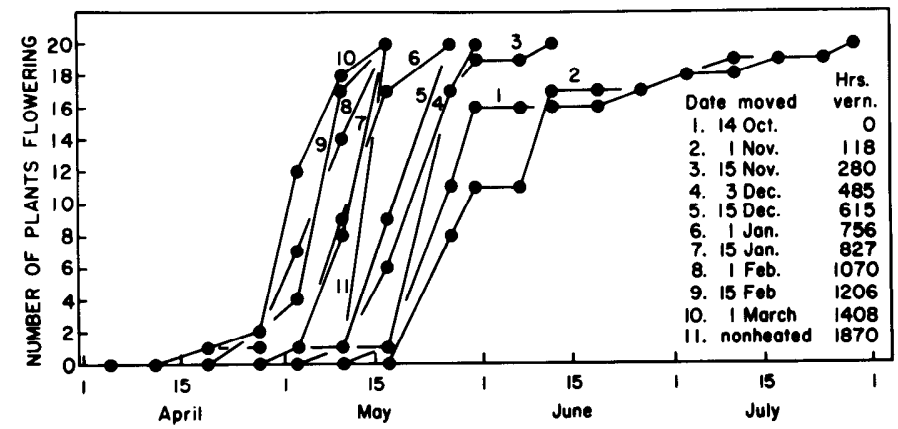

Fig. 1. Effect of vernalization of flowring of Bromus japonicus plants.

flowered in the LD chamber after 80 days, while none of the plants flowered in the SD chamber after 168 days.

\section{Discussion}

Germination tests of $B$. japonicus were performed at tempcratures regimes that approximate the daily average maximum and minimum monthly temperatures in northcentral Kentucky $5 \mathrm{~cm}$ above bare soil (Jerry Hill, Advisory Agricultural Meteorologist unpublished): July and August, $35 / 20^{\circ} \mathrm{C}$; September, $30 / 15^{\circ} \mathrm{C}$; October, 20/10 $\mathrm{C}$; November and March, $15 / 6^{\circ} \mathrm{C}$; April, $20 / 10^{\circ} \mathrm{C}$; and May and June, $30 / 15^{\circ} \mathrm{C}$. Germination data from seeds incubated at these temperatures allow one to extrapolate laboratory results to the field.

From the time of maturity in late June and early July until December when temperatures drop to near freezing, habitat temperatures are suitable for the germination of $\boldsymbol{B}$. japonicus seeds (Table 1). Thus, seeds can germinate at any time from July to November, if they are dispersed and there is sufficient soil moisture. Even seeds that are dormant when they are freshly matured quickly afterripen and can germinate over the range of habitat temperatures in late summer and autumn in both light and darkness. Lack of germination of some seeds in a given seed crop is attributed to delay of seed dispersal rather than to inherent dormancy or to unfavorable germination temperatures in the habitat. Seeds that are dispersed during winter, when temperatures are near freezing, are induced into dormancy and thus can not germinate during spring and early summer. Although temperature and soil moisture conditions in the habitat during spring and early summer would promote germination of nondormant $B$. japonicus seeds, very few seedlings can be found in the habitat in spring. During summer the dormant seeds afterripen (come out of dormancy) and by autumn they are capable of high percentages of germination at September $\left(30 / 15^{\circ} \mathrm{C}\right)$ and October $\left(20 / 10^{\circ} \mathrm{C}\right)$ temperatures (Table 1).

Lower, winter temperatures have been shown to induce dormancy in imbibed, nondormant seeds of the winter annuals Alopecurus myosuroides Huds. (Wellington and Hitchings 1966), Phacelia dubia (L.) Trel. var. dubia McVaugh (Baskin and Baskin 1973), Torilis japonica (Houtt.) DC. (Baskin and Baskin 1975) and Sedum pulchellum Michx. (Baskin and Baskin 1977). Following low temperature induction into dormancy, seeds of these species were stored under natural or simulated summer temperature regimes. In all cases, dormancy disappeared and high germination percentages were obtained. In $P$. dubia var. dubia it has been shown that the high temperatures characteristic of the habitat in summer actually are required for afterripening of seeds in secondary dormancy (Baskin and Baskin 1978).

The large number of seedlings (558) that appeared in the blocks of soil collected in the $B$. japonicus habitat indicates that viable, ungerminated seeds can persist in or on the soil for at least several months (i.e., from the time of dispersal in winter until the following autumn). This lends support to our conclusion that much of the annual population establishment is from seeds other than those produced in the current year. Since only three B. japonicus seeds germinated in the soil blocks the second autumn after they were transferred from the field to the nonheated greenhouse, it is believed that most of the seeds that are dispersed during winter and spring germinate the following autumn. Therefore, most of the seeds that germinate at a population site in a given year are probably from the previous year's seed crop, rather than from a reserve of seeds which has accumulated over several years or from seeds produced in the current year. Chepil (1946) observed that seeds of the winter annual Bromus tectorum L. germinated in the field the second year after they were produced but few viable seeds persisted thercafter.

In B. japonicus, habitat temperatures do not play a very large role in controlling the timing of germination until temperatures drop to near freezing in winter. From immediately after seed maturation until winter, seeds can germinate over a wide range of temperatures, including those that prevail in the habitat during summer and autumn; therefore, germination during this time is controlled by time of dispersal and availability of soil moisture. Low, winter temperatures prevent germination and induce a large portion of the seeds into dormancy. Thus, spring germination is prevented, regardless of the favorability of habitat factors. Lack of germination in spring is of possible survival value to the species because it prevents germination at a time of the year when soil moisture conditions may become too limited for growth and maturation and when (as will be discussed later) photoperiod conditions may inhibit flowering. The loss of dormancy during summer allows the seeds to respond to favorable temperature and soil moisture conditions for germination in autumn. Thus, the seedlings become established at a time when soil moisture allows growth and survival for the following 7 to 8 months and when the vernalization and/or photoperiod requirements for flowering subsequently will be fulfilled.

A number of workers have observed that seeds of B. tectorum lie over from one year to the next in the litter and soil (Young et al. 1969, Hull and Hansen 1974, Young and Evans 1975). Some of these seeds apparently can germinate in spring if there is abundant soil moisture (Chepil 1946, Klemmedson and Smith 1964, Young et al. 1969, Hull and Hansen 1974), but others failed to germinate in spring because they were induced into dormancy during winter at temperatures too low for germination (Warg 1938, Young et al. 1969, Hull and Hansen 1974, Young and Evans 1975). Young and Evans (1975) found that by May the winter-acquired dormancy was breaking down, and seeds began germinating at a slow rate.

In the winter annuals Bromus tectorum and B. commutatus Schrad., short day (SD) photoperiodic regimes followed by exposures to long days (LD) stimulate flowering. Plants of these two species grown under $\mathrm{L}$ and SDs in a heated greenhouse failed to flower under continuous SDs or continuous LDs. However, when plants were grown under SDs for 1 month and then transferred to LDs they flowered (Finnerty and Klingman 1962). In another bromegrass, $B$. inermis Leyss., a perennial, plants must be grown under SDs and low temperatures before being subjected to LDs, if they are to flower (Newell 1951). Subsequent studies have revealed that floral induction in $B$. inermis begins when plants are exposed to SDs and is completed after plants are removed to LDs (Kirshin et al. 1977).

In $B$. japonicus LDs were required for flowering. Regardless of whether or not plants had been previously vernalized, plants flowered in the LD but not in the SD chamber, and they did not flower under natural photoperiods in the heated greenhouse until after the daily photoperiod was $12 \mathrm{hr}$ or longer. Flowering of nonvernalized plants under natural LD regimes in the greenhouse and in the LD chamber suggests that exposure to SDs prior to exposure to LDs may stimulate flowering. Since nonvernalized plants were kept in the heated greenhouse under natural photoperiods during autumn and part of the winter, they were exposed to SDs for several months. As in the winter annual bromegrass studied by Finnerty and Klingman (1962), flowering occurred in LDs after plants had received a number of SDs. 
Vernalization followed by exposure to LDs promoted flowering in B. tectorum and B. commutatus. Imbibed seeds of these species were stored in darkness at $3.3^{\circ} \mathrm{C}$ for 7 to 30 days and then planted on soil under long and short days. The resulting plants grown under LDs flowered by those grown under SDs failed to flower. Also, increases in the vernalization period from 7 to 30 days resulted in a decrease in the time to flowering of plants grown under LDs (Finnerty and Klingman 1962).

Although vernalized plants of $B$. japonicus also were exposed to SDs, vernalization per se had a stimulatory effect on flowering. In the heated greenhouse (Fig. 1) and in the LD chamber, vernalized plants flowered much sooner than did nonvernalized plants. Thus, photoperiod and temperature may act together to help control the time of flowering in B. japonicus. Plants can flower without vernalization if they are subjected to the natural autumn-winter-spring sequence of photoperiods. However, vernalized plants flowered in early to mid May, while in nonvernalized plants flowering was delayed until late May, June or July (Fig. 1). Flowering in early May as opposed to late May, June, or July is of possible survival value to the species, because plants that fail to flower in May are more likely to be killed hy drought before they have had a chance to flower and/or set seeds.

In a series of field experiments in Lincoln, Nebraska, Finnerty and Klingman (1962) sowed seeds of B. japonicus at various times from early September to late April and followed the fate of the resulting plants. When plantings were made before March 1, the plants produced many seeds during June. However, plants from seeds planted after March 1 only produced occasional seeds in late summer, and in plants from seeds planted after April 1 panicle production seldom occur red. Finnerty and Klingman (1962) noted that summer survival of plants from seeds that germinated in late spring was low and said that, "death appeared to be caused by a combination of diseases, summer heat, and drought." The failure of plants from late-spring plantings to flower in carly summer was, no doubt, due to the fact that seedlings did not receive either vernalization or SDs before they were subjected to LDs of early summer. Some of the plants from seeds that Finnerty and Klingman (1962) planted in April survived but they did not flower until the second year-after they had received SDs and vernalization during the intervening winter.

If $B$. japonicus seeds do not germinate in the autumn of the year in which they are produced, several events could occur. One, the viable, nondormant seeds in the soil may be induced into dormancy during winter, and germination would be delayed until the next autumn, after the seeds had come out of dormancy during the summer. Two, seeds on the soil may be vernalized during the winter and germinate the following spring and the resulting plant flowers and sets seeds. Three, seeds may remain on the dead, erect plants until spring when habitat temperatures are too high for induction into dormancy or for vernalization. The nondormant seed would germinate if soil moisture was sufficient, but the resulting plant would not flower until the following spring after it received vernalization and SDs during winter; that is, if it survived the summer heat and droughts. The presence of large numbers of $B$. japonicus seeds in soil blocks collected in the habitat and the field observations that (1) many seeds germinate in autumn before most of the current year's seed crop is dispersed, (2) only a few newly-germinated seeds can be found in the habitat in spring and (3) no vegetatively active plants are in the habitat during summer verify the germination data (Table 1) showing that many of the ungerminated B. japonicus seeds present at a population site in autumn are induced into dormancy during winter and do not germinate until the next autumn.

\section{Literature Cited}

Baskin, J.M., and C.C. Baskin. 1973. Delay of germination in seeds of Phacelia dubia var. dubia. Can. J. Bot. 51:2481-2486.

Baskin, J.M., and C.C. Baskin. 1975. Ecophysiology of seed dormancy and germination in Torilis japonica in relation to its life cycle strategy. Bull. Torrey Bot. Club 102:67-72.

Baskin, J.M., and C.C. Baskin. 1977. Germination ecology of Sedum pulchellum Michx. (Crassulaceae). Amer. J. Bot. 64:1242-1247.

Baskin, J.M., and C.C. Baskin. 1978. Temperature requirements for afterripening of seeds of a winter annual induced into secondary dormancy by low winter temperatures. Bull. Torrey Bot. Club 105: 104-107.

Baskin, J.M., and C.C. Baskin. 1979. The ecological life cycle of Thlaspi perfoliatum and a comparison with published studies on Thlaspiarvense. Weed Res. 19:285-292.

Chepil, W.S. 1946. Germination of weed seeds. I. Longevity, periodicity of germination, and vitality of seeds in cultivated soil. Sci. Agr. 26:307-346.

Fernald, M.L. 1950. Gray's Manual of Botany. 8th ed. American Book Co., New York.

Finnerty, D.W., and D.L. Klingman. 1962. Life cycles and control studies of some weedy bromegrasses. Weeds 10:40-47.

Hitchcock, A.S. 1935. Manual of the Grasses of the United States. U.S. Dep. Agr. Misc. Pub. Number 200. Washington, D.C.

Hull, A.C. Jr., and W.T. Hansen, Jr. 1974. Delayed germination of cheatgrass seed. J. Range Manage. 27:366-368.

Kirshin, I.K., G.S. Stefanovich, and Zh. N. Shcherbina. 1977. Flora induction of awnless bromegrass in regimes of decreasing and increasing photoperiod. Soviet J. Ecol. 8:101-105.

Klemmedson, J.O., and J.G. Smith. 1964. Cheatgrass (Bromus tectorum L.). Bot. Rev. 30:226-262.

Leopold, A.C. 1964. Plant Growth and Development. McGraw-Hill Book Co., New York.

Newell, L.C. 1951. Controlled life cycles of bromegrass Bromus inermis Leyss., used in improvement. Agron. J. 43:417-424.

Slife, F.W., K.P. Buchholtz, and T. Kommedahl. 1960. Weeds of the north central states. Univ. Illinois Agr. Exp. Sta. Cir. 718. Urbana, Illinois.

Steyermark, J.A. 1963. Flora of Missouri. Iowa State Univ. Press. Ames, lowa.

Warg, S.A. 1938. Life history and economic studies on Bromus tectorum. M.S. Thesis. University of Montana. Missoula, Montana.

Wellington, P.S., and S. Hitchings. 1966. Germination and seedling establishment of blackgrass (Alopercurus myosuroides Huds.) J. Nat. Inst. Agr., Bot. 10:262-273.

Young, J.A., and R.A. Evans. 1975. Germinability of seed reserves in a big sagebrush community. Weed Sci. 23:358-364.

Young, J.A., R.A. Evans, and R.E. Eckert, Jr. 1969. Population dynamics of Downy brome. Weed Sci. 17:20-26. 